\title{
シニレーゲルアオガエル雄の繁殖期における 水田利用空間の特徵
}

The characteristics of paddy field space for male Rlacophorus schlegelii in breeding period.

\author{
大澤 啓志* 勝野 武彦* \\ *Satoshi OSAWA * Takehiko KATUSNO \\ (*日本大学生物资源科学部緑地・環境計画学研究室) \\ (* Lab. of Landscape Science and Planning, Coll. of Bioresource Sciences, Nihon Univ.)
}

\section{1 はじめに}

日本的な農村景倠は水田によって特徽付けられ ており，水田における生物の利用状況を明らかに することは農村域における生物相の保全上重要で ある。本研究では，本田環境に適応して生息・繁 殖している生物群である両生類に着目し，特に水 田構造がその繁殖に梁く関方っていると考えられ るシュレーゲルアオガエル (Rlacophorus schlegelii）を対象とし，䡔殖期における水田内の 利用状況をみた。

水田の構造は，畦畔に囲まれた水田区画が基本 的な単位となっている。また，灌水・排水のため の水路む付随する椿造物であるが，「田越し潅溉」 では水路を久く場合もある。水田を利用する雨生 類のほとんどの種は水田区画内の水域や流れの少 ない水路で産卵するのに対し，シュレーゲルアオ ガエルは畦畔等の土中に泡状の卵塊を産み付ける 独特な繁殖形態を有している。土中に産卵するの は，捕食されやすい化直後の幼生を守るため， また卵塊の乾燥を防ぐためと考えられている4!。 卵塊は約 1 週間で稃化し6), 幼生は雨水等により 畦内から水田の水面に流れ落ちて以降オタマジャ クシとして生活する。水田耕作の暦では，本種の 繁殖時期に重なる期間に畦鈝りと水田面への湛水 が行われる。これにより幼生の生活する陽光の浅 い水域に接した状態で，産卵に必要な軟らかい土 壁が毎年形成され，水田は本種の生息に㰒めて都 合の良い環境となってきた。
しかしながら近年本種の減少について，谷戸水 田では甬場整備による乾田化が生息密度を低下さ せる11)ことや，司状地平野の水田では個体供給 のある丘陵地・山地の付近を除いては生息が見ら れない12）等が報告されている。全国的に雨生類 の减少が危惧される今日 ${ }^{5)}$ ，農村整備における健 全な水四生態系の維持・保全には，それぞれの種 について減少要因を一つひとつ明らかにしていく 作業が不可欠である。そこで，シュレーゲルアオ ガエル保全のための基礎的知見を得ることを目的 に、繁殖期における水田空間と本種雄のその利用 の関わりについて研究を行った。

\section{II 材料および方法}

調査は，神奈川県横浜市南部の舞岡公園の小規 模な谷戸水田（瓜久保：低湿地部約 1.6ha）にお いて行った。対象地は田園景観を保全した形で整 備された公園内にあり，水田の管理は市民グルー プが行っている9)。当該地は，周囲の市街化に伴 い都市内で孤立した緑地となっているが，隣接す る市街化調整区域の農地とともに比較的まとまっ た規模の緑地を形成している。多摩丘陵中南部の シュレーゲルアオカエルの生息量を広䇶囲に調べ た大澤・勝野 $(2000)$ 11)によると，本調査地を 含む舞岡公園は本種が特に多く生息している緑地 とされる。調䍒地の谷戸内には，下流側に 4 筆の 水田（湿田）が，上流側には数筆の休耕田湿地が 存在している。休耕田湿地においても本種の鳴き 


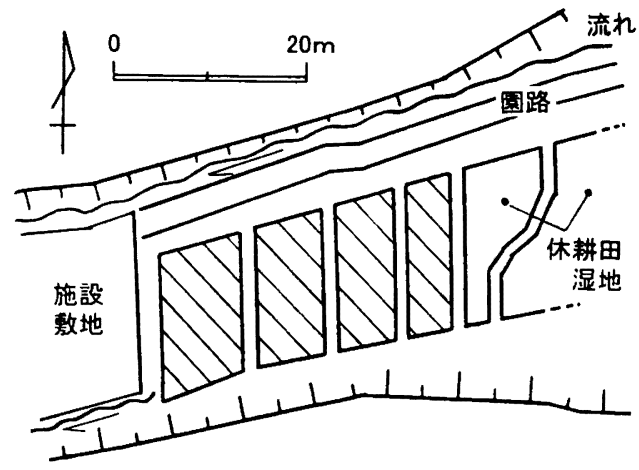

図 1 調査地の概要（斜線部：対象水田）

声が若干認められたが，草に覆われ調査が著しく 困難なため下流側の水田を主な調查刘象地区とし た(図 1)。

シュレーゲルアオガエルは，本州・四国・九州 の低地から千数百 $\mathrm{m}$ 程の高地まで広く見られるア オガエル科の小型のカエルである ${ }^{8)}$ 。非繁殖期に は草や潅木の上で生活しているが，繁殖は水田や 湿地, 池岸などで行方れる。本地域では 3 月下旬 〜 6 月中旬が本種の繁殖期であり ${ }^{10)}$, 雄は夜間, 水田に集まり盛んに鳴き声（Mating Call）を発す る。人が近づくと一旦鳴き止むが位置を移動する ことは少なく，調査者がしばらく静かに止まって いるとまた鳴き始める。この鳴き声を頼りに個体 の位置を確認し，水田構造のどの位置で鳴いてい たかを記録する方法によった。しかしながら本種 の場合，土の中や植物下で鳴いている個体も存在 するため，目視による確認だけでは不十分である ことが事前に予想された。そこで，長い柄の先に 小型マイクを付汁た局所集音装置を作成して，草 の中や土中の個体についても発見できる手法 ${ }^{131}$ も䪔助的に用いた（図 2)。また調查は，日が暮れ て十分暗くなってから開始し，20:00〜0:00 内 に収まるように努めた。

確認した個体は，以後の観察が容易になるよう， 番号を書いた蛍光テープ（約 $1 \times 1.5 \mathrm{~cm} ）$ を背に装 着した。これは確認初回時に捕獾し，約 $10 \%$ アル

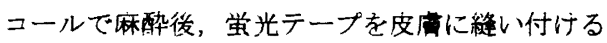

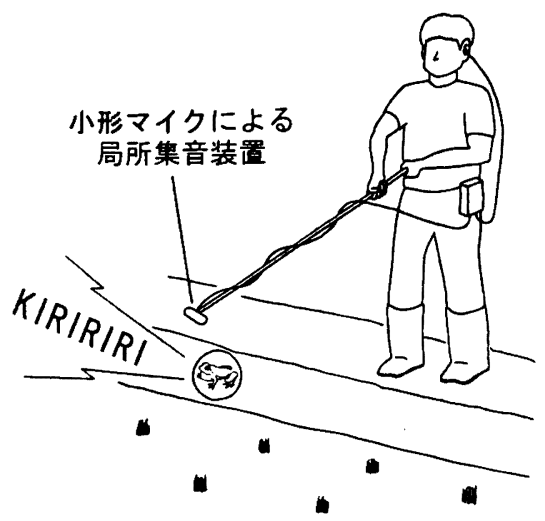

図2土中にいる倜体の発見手法

方法によった。これは，2 回目以降に営光テープ により高い発見率が得られるとともに，捕獲しな くてもテープ番号を読み取ることで個体識別が可 能となるためである。

\section{III 結果}

調查は, 2000 年 4/18 6/9 内で延べ 23 日行い， 総調査時間は 58 時間 (平均 2.52 時間/日) に達し た。各調査日の $21: 00$ 前後の気温は, 最低 $10.5^{\circ} \mathrm{C}$, 最高 $22.0^{\circ} \mathrm{C}$, 平均 $15.9^{\circ} \mathrm{C}$ であり，また天候は，晴 れ 6 日，渱り 12 日，雨 5 日であった。また，夜明 け時の行動を見るため， $5 / 16 ， 18$ には早朝の観察 も行った。調査期間内にシニレーグルアオガエル 雄を 60 個体確認し,内 2 回以上の確認が得られた のは 33 個体であり，延べの確認回数は 151 回に及 んだ。

シュレーダルアオガエル雄の確認位置について プロットしたものが図 3 である。概観して，畦畔 付近に集中していた。水田空間としては畦畔と水 田区画内部に大別されるが，水田区画内であるが 畦付近で確認される個体も多く認められた。この ため, 今回は水田の利用空間を畦畔側面・畦際水 田内（畦加ら約 $50 \mathrm{~cm}$ 以内0水田区画内）・水田区 画内（畦から約 $50 \mathrm{~cm}$ を超える水田区画内）の 3 つの区分を用いて以下に解析した。確認回数とし ては畔畔側面と畦際水田内が非常に多く，両利用 
誢查日：4/1,8, 21, 22, 25, 26, 28, 29, 30 ,

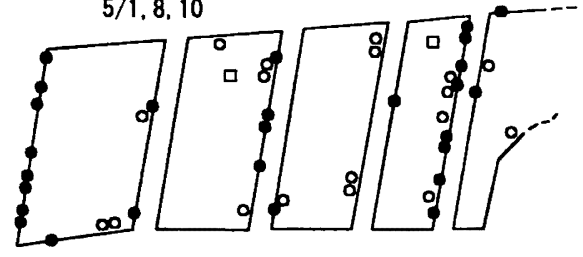

調套日：5/12, 14, 15, 16

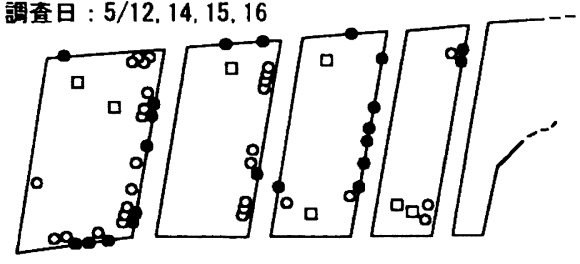

調查日：5/17, 18, 23, 24, 26, 28, 6/2, 9

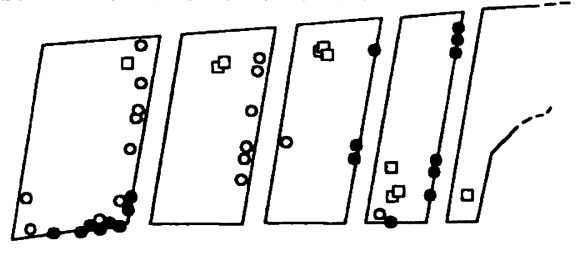

○硅畔側面 ○眭際水田内 口水田区画内 $\leftarrow$ 下流侧・上流侧 $\rightarrow$

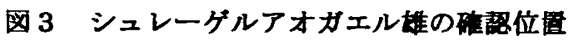

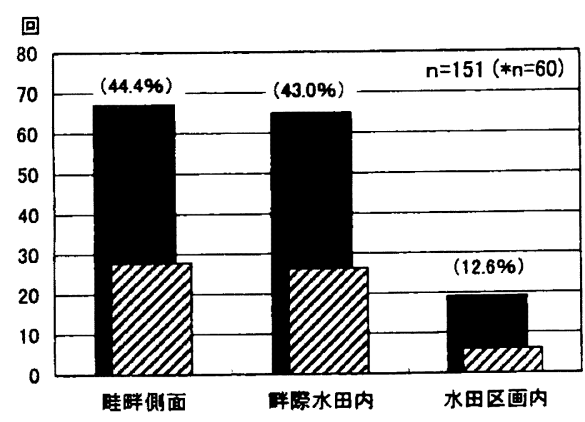

*斜線グラフは個体当りの確鮚頻度に直した値。

図4水田利用空間区分別のシュレーゲル アオガエルの礁詺回数

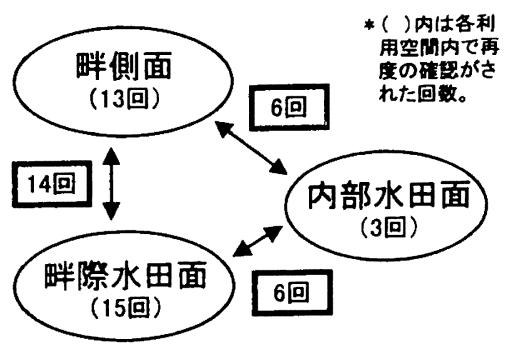

図 5 水田利用空間間での移私回数 （裉数回礁認倜体による）

表 1 隹位传における水田利用空間区分別 の立地区分割合
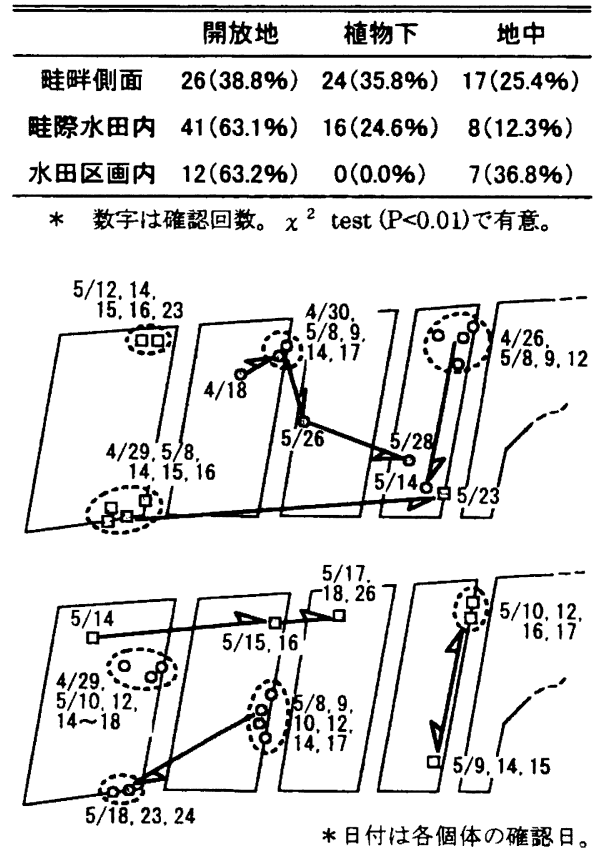

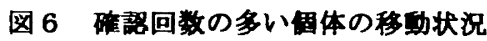

空間を合わせると全体の 8 割弱を占めていた（図 4)。また，個体当たりの確認割合注1)に換算して も, 同様な傾向を示した。

複数回確認された個体（33 個体）について，3 つに区分した利用空間間での前回から次の確認位 
置一の移動状況をみると，畦畔側面，畦際水田内 およびその両利用空間間で移動している個体が多 くなっていた（図 5)。さらに確認回数が多い個体 についてその確認位置の変化をみたところ(図 6), 一定期間同一個所に留まる傾向が認められた。ま た，時には急に離れた位㯰に移動し，そこでまた 一定期間留まる個体も見られた。

確認位置の立地（地中・植物下・開放地に区分） については, 確認回数としては開放地が最も多く 全体の約半数を占めていた（表 1)。さらに水田の 利用空間との関係では, 畦際水田内では開放地で 多く地中で少ない，また水田区画内では開放地で 多く植物下で少ない, といった傾向が見られた $(x$ ${ }^{2}$ test : P<0.01)。しかし, 今回のように補助的に探 查機器を用いてはいるものの目視が中心の調査で は，開放地ほど発見しやすいといった発見率の差 異も影郘していると考えられる。地中個体の確認 回数は畦畔側面が最も多く, 畦際水田内・水田区 画内ではそれぞれ約半数ほどの確認であった。地 中で確認された個体は，ほとんどが地表から5〜 $10 \mathrm{~mm}$ 以内の非常に浅い場所での確認であり（図

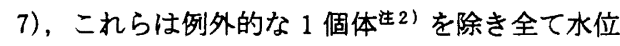
面よりも高い位置の地中に空隙を形成していた。

なお，早朝時の調査においては，夜明けになる と(1)位圈を変えない(地中にいた個体), (2)水田内 の水面下の軟らかい土中に潜り込む，(3)周囲の樹 林地に移動する，といった行動が観察された。

\section{IV 考察}

本研究では，水田の利用空間別の確認回数とい う指標値で利用の定量評価を行った。調査日時は 任意であるが，繁殖ピーク期間を中心とした最も 多く本種の雄が水田に現れる時期に調查を行うと ともに, 目視および探査機器を用いて調查時間内 に確認できた全ての個体を記録する方法を用いた。 これは，(1)調査日毎の条件の不均質性を無視でき るほどの調査量の確保，(2)調査筑囲に対しての悉 皆的に均質な調査努力，を満たしていると考えら れ, 確認回数という指標値を用いて雄が鳴く位置 やその立地環境についての利用傾向を把握するこ とは可能であると判断し, 本種雄の利用空間の嗜

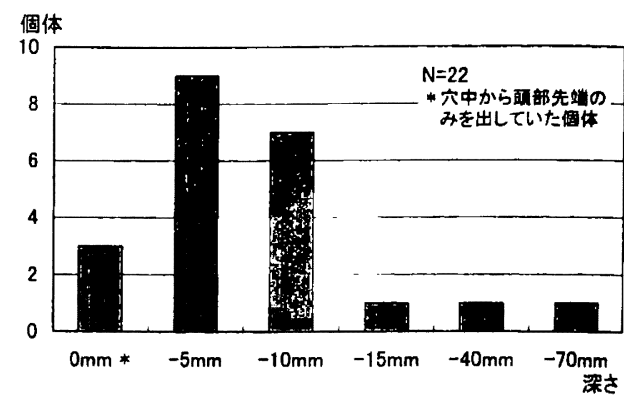

図 7 地中確認時の地表からの深度

好性として解䣋した。

調查の結果, 本種雄が畦畔および畦付近の水田 内を高い頻度で利用していることが明らかにされ た（図 3・4）。本種の皆は䋈殖時には短期間しか 水田に留まらない2) のに対し，今回長期にわたり 複数回再確認された雄も多かった。このため本種 の雄については，少なくとも一部の個体は繁殖期 間中に長く水田付近に留まることが示された。し かしながら，再捕攃されなかった個体や再確認期 間が非常に短い個体も多くなっている（図 8)。す なわち長期間水田に留まらない雄も多く存在する と考えられ，殖期間中に個体の入れ替わりが生 じているものと推察される。

体長 (頭胴長) の階釉別に複数回確認の状況を みると，小さな個体ほど再捕獾までの期間が短く なる傾向が見られている（図 8)。調査日の間隔が 不均一であるため蕨密なものではないが，小型個 体 $(32 \mathrm{~mm}$ 以下) は, 再確認の期間は 10 日以内が ほとんどとなっていた。一方，一度も再捕攃され ない大型個体（35mm 以上）も多く，大きな個体 が常に長期間水田に留まるわけではない。

一方, 確認回数の多い雄個体は一定期間同一個 所に留まることから (図6), 特定の位置への定着 性を持つと考えられる。畦畔および畦付近の水田 内の間では日により位置を変えることも多いが, 水田区画内までも含めて位置を変えることは非常 に少なかった (図 5)。これらのことより繁殖期に 本種の雄は, 畦畔を中心に付近の水田内も含めた 位圆に好んで定着する簌囲を形成しているものと 推察される。ただし，鳴きながら動き回る雄も見 
個体

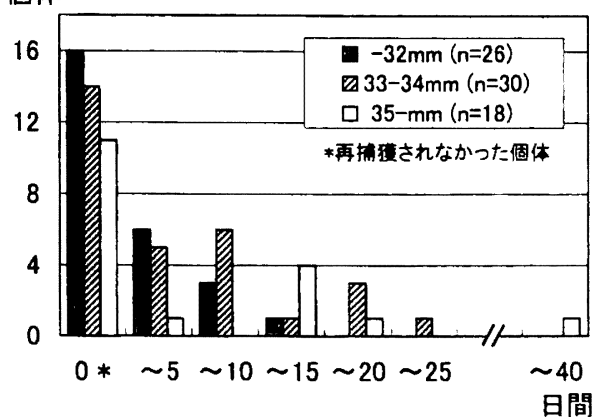

図8 体長別による再捕獾までの日数

られる゙!ため, 全ての雄個体が定着する䈇围立形 成するかについては現時点では不明である。

確認位置の立地状態の選択性については, 今回 の調查ではあまり明らかにはできなかったが，遮 蔽物のない開放地でも多くの個体が確諗されてい た（表 1)。特に湿度・気温の高い調查日には，乙 れまで地中に確認されていた個体が地表に出て鳴 いているのも観察されている。すなわち本種の立 地の選択性は, 湿度队気温等による可变性有し ていると考えられる。また，地中での確認は畦畔 側面が多いものの，水田内（畔際水田内十水宙区 画内）での確認も多く見られた。これら水田内で の確認は，荒起こしによる凸状の土塊を利用して いた個体である。冬期の荒起こし作業による水位 面上にでる凸状土塊の形成は，畦畔だけでなく水 田内にまで本種が利用できる空間を広げる効果が あると考えられる。

さらに，水田区画内およで近接した休耕田湿地

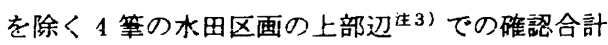
注83 回 (畦畔側面十畦際水田面) となり, 同様に 下部辺 16 回, 側辺 29 回であった（図 3)。水田区 画の上部辺は, 一段上の水田から水が溜み出るこ とで降雨が続かなくても溜まり水が形成されやす い環境であることが関与していると推察される。 このように，畦畔と水田区画といった水田構造に 加えて, さまざまな要因が本種雄の繁殖位䈯の選 択に関与している。

水田構造における本種雄の畦畔への嗜好は, 産
卵場所が畦畔侧面の土中が多いことを考え合わせ ると極めて合目的な空間利用上なっている。そし て谷戸田のように地形勾配に沿って小規模な区画 を多数有する伝統的な形態の水田は，水田面積に 対寸る長い畦畔総延長という点からも本種に上っ て安定した繁殖環境であると言える。一方、畘畔 総延長の減少をもたら寸面場整備による大区画水 田人の転換は，本種の慗殖に书いて何らかの負の 作用を引き起こしている可能性が忍る。しかし， この点は現段階では十分には明らかにはされてお らず今後実証的な調査が必要である。

一方, 繁殖期閒中の日中の隐れる場所について も利用状況の把握が救められる。今回, 水田の土 中もしくは周囲の樹林の利用が観察されたが，定 量的な利用頻度の把握にまでは到っていない。 らに，両生類がその生活環をまっとうするには箱 殖・産卵のみならず, その後の幼生期間における 水域の確保も重要な条件となる。圈場整備後の乾 田において田植えの直前まで湛水されないことが, 本種生息に負の要因となっているという指摘 ${ }^{111}$ も既になされている。またシュレーゲルアオガエ ルの越冬場所を調ぐた Thara（1999）》によると， 軟らかく湿った土壤を好み, 谷戸の沢や池の周り の限られた筑囲の浅い土壤中で越冬するとしてい る。本種の保全には，このように繁殖期以外につ いても考虑する必要があり，本田およびその周辺 も含めた生息環境の確保が求められる。

\section{V おわりに}

日本では 2000 年以上前から続けられてきた氷 田において，その畦畔に囲まれた水田区画という 基本的な構造は現在も変方りない。その畦畔之水 田区画の接点を特異的に繁殖環境としている生物 が存在することは，水田における農業上生物生息

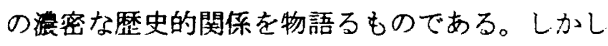
一方で, コンクリート畦や畦マルチの普及が進め ば，すぐに本種が生息できない水田が広籍囲に出 現することも容易に予測される。

田んほのカエルに代表される両生類は，一般に 高次の捕食者の重要なエネルギー資源（䬣）上な っており，両生類の减少は捕食生物に深刻な影響 
を及ぼしてる1。加えて，水田農業を基層文化 としてきた我々日本人とカエル頼の長く深い結び つきは，既に文化的なものにまで昇華されている 14）。豊かな農村環境整備に向けて，それぞれの 種について基本的な空間利用を明らかにしながら， 水田耕作サイクルにおける各作業時期および作業 内容ごとに生産活動と相容れあえるような両生類 保全のための管理手法生4) を確立していくことが 課題である。

\section{[注橎]}

注 1) 個体当たりの碓認割合：1回のみと被数回礁视の個 体間の回数差を除く意味で，それそれの個体について (各区分の碓楒回数) /(確䛱回数)で計算した值。 $\mathrm{n}=60$ になる。

注 2) アメリカザリカニ等別の生物が掘った穴内にいた個

体。地下約 $70 \mathrm{~mm}$ 程の穴奥で鸣いていたが，穴内には ほとんよ゙水はしみ込んで拈らず, その意味では穴内の 水位面より上で鸣いていたこ上になる。

注3）谷可における水の流れの向きに対し，四角形である 水田一等の各辺をそれぞれ「部辺」「下部辺」側辺」 とした。

注 4）例えぼ、早春期に産卵する両生類のために乾田でも 2 月頃から部分的に水を張る、水田脇に璖めの溜まり を設けて中千しの際に幼生の避難場所にする、といっ たエ夫など。

\section{[引用文献]}

1) Blaustein A. R. and D. B.Wake (1990): r Declining amphibian populations: a global phenomenon?」 Trends in Ecology and Evolution, Vol. 5. pp. 203-204

2) 福山欣司・草野保・宮下徳子（1991）：「シュレーゲル アオカエルの崔の第殖場所での行動追跡」爬虫两楼類 学雑誌, Vol. 14, No. 2, pp. 96
3) Fukuyama K. (1991): ISpawning behaviour and male mating tactics of a foam-nesting treefrog, Rlacophorus schlegelii.」 Animal Behaviour, Vol. 42, No. 2, pp. 193-199

4）福山欣司（1996）:「アホガエル類」、『日本峌物大百科 5 两生類 - 爬虫類 - 故骨魚類 (日高敬隆監修)』平凡 社, 東京, pp. 46-49

5）長谷川雅美・草野保・福山欣司（2000）: r日本におけ る両生類個体群诚少の認識過程」千葉中央博物館自然 誌研究報告特別号, Vol. 3, pp. 1-7

6）比婆科学教育振興会（1996）: 『広島紧の両生・爬虫類』 中国新閶社, 広岛, $196 \mathrm{pp}$.

7) Thara $S$. (1999) : ISite selection for hibernation by the tree frog, Rhacophorus schlegelii.J Jpn. J. Herpetology, Vol. 18, No. 2, pp. 39-44

8）前田害男・松井正文（1989）：『日本カエル図文一 総合出版, 東京, 206pp.

9）大澤啓志（1999）：「都市域の谷戸の文化装圈性一横浜 市舞岡公園の展的襄境保全」緑の珫本（公害対策技術 同友会)，Vol. 49, pp. 59-64

10）大澤啓志・勝野武彦（1999）:「都市緑地における啨き 声によるカエル個体数把握の有効性について」舆境倩 報科学論文集, Vol. 13, pp. 49-54

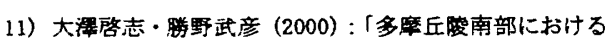
シュレーゲルアオガエル生息の㻴境条件の把暒と保全 に関する考察」ランドスケープ研究, Vol.63, №.5, pp. $495-500$

12）大澪啓志・勝野武彦 (2001)：「䎊状地水田地带におけ る水田の地形分類とカエル類の分布に関する研究」 村計画学会誌, Vol. 19, No. 4, pp. 280-288

13）大摆啓志・勝野武彦 (2001):「水田案殖におけるシュ レーゲルアオガエル雄の活動及びその捕塔手法」爬虫 両椿類学会報, Vol. 2001, No. 1, pp. 48-49

14）碓井益婎（1989）：『蛙 ものと人間の文化史 64』法 政大学出版局, 東京, 367

To keep biodiversity in rural district, it is necessary to estimate the management level on paddy rice cropping for amphibian. We investigated where the male Rlacophorus schlegelii appeared on space of paddy fields in breeding season. The calling points of the inale frogs were plotled by whereabouts survey at night. They appeared frequently on ievees or paddy field surfaces of ciose to levee. As the resuits of individuai marking, the maie $R$. scriegeiii tend to stay on particular smaii range. Thus, we suggest that the maie $R$. schlegelin form the behavior range in the neighborhood of levees. And, distributions of male frogs in paddy fields were concerned with various factors, e.g. lumps of earth, remaining pools. In future, our task is to clear the habitats uses of another amphibian species on paddies, too. 